СОФьИН Дмитрий Михайлович - кандидат исторических наук, доцент кафедры междисциплинарных исторических исследований Пермского государственного национального исследовательского университета (614990, Россия, г. Пермь, ул. Букирева, 15; sofjindm@yandex.ru)

СОФЬИНА Марина Владимировна - кандидат исторических наук, доцент кафедры библиотечных и документально-информационных технологий Пермского государственного института культуры (614000, Россия, г. Пермь, ул. Газеты «звезда», 18; mar-sofina@mail.ru)

\title{
ГЕНЕРАЛ-ГУБЕРНАТОР В ДЕЙСТВИИ: ВЕЛИКИЙ КНЯЗЬ СЕРГЕЙ АЛЕКСАНДРОВИЧ И ДЕЛО Е.М. ВОЗНЕСЕНСКОЙ
}

\begin{abstract}
Аннотация. На примере дела потомственной почетной гражданки Е.М. Вознесенской рассматриваются действия московского генерал-губернатора великого князя Сергея Александровича по решению проблем душевнобольных жителей. В статье, основанной на ранее не опубликованных документах из фондов Государственного архива Российской Федерации и Центрального государственного архива города Москвы, показывается внимание, которое губернские власти уделяли отдельным лицам и конкретным обстоятельствам даже в условиях напряженной работы по подготовке коронационных торжеств 1896 г. Ключевые слова: великий князь Сергей Александрович, дом Романовых, Московская губерния, генерал-губернатор, социальная политика
\end{abstract}

$\mathrm{B}_{\mathrm{H}}^{\mathrm{s}}$ достаточно обширной на сегодняшний день историографии, посвященной великому князю Сергею Александровичу, значительное внимание уделялось его деятельности на посту московского генерал-губернатора [Боханов 1997; Гришин 2006; На службе у России... 2013; Великий князь... 2015; Великий князь... 2017; Софьин 2021]. Вместе с тем многие направления деятельности великого князя в качестве руководителя Москвы еще требуют исследования, в частности политика в отношении лиц, страдавших душевными расстройствами. Рассмотрение в качестве примера случая с Е.М. Вознесенской позволяет приблизиться к пониманию данной сферы деятельности августейшего генерал-губернатора.

Занимая должность московского генерал-губернатора, великий князь Сергей Александрович в рамках служебных обязанностей должен был принимать участие в судьбах большого числа очень разных людей. Даже напряженная работа в первые месяцы 1896 г. по подготовке к московским коронационным торжествам в связи с венчанием на царство императора Николая II, племянника великого князя, не избавляла генерал-губернатора от обычной текущей деятельности. Много времени занимали доклады подчиненных и прием различных посетителей. В дневнике Сергея Александровича, в т.ч. и в записях начала 1896 г., постоянно встречаются фразы «принимал все утро», «принимал усиленно», «принимал много», «принимал очень много», «принимал ужасно много», «принимал без конца», «ужасно длинный прием», «прием одуряющий», «принимал до одури», «принимал до одурения».

В Центральном государственном архиве города Москвы, в фонде канцелярии московского генерал-губернатора отложилось множество дел, которые показывают в действии социальную политику губернских властей и лично великого князя Сергея Александровича. Среди данных документов находится

1 ГАРФ. Ф. 648. ОП. 1. Д. 32. Л. 4(об), 5, 7(об), 11, 12(об)-13(об), 15, 16, 18, 19(об), 25(об), 26(об), 27 (об), 28(об), 30, 32. 
дело потомственной почетной гражданки Елены Матвеевны Вознесенской. В конце 1895 г., 11 декабря, Е. М. Вознесенская подала прошение на имя августейшего генерал-губернатора, в котором сообщила о нападении на нее, происшедшем у Рязанского вокзала Москвы 1 февраля того же года, и пожаловалось, что инцидент не расследуется должным образом ${ }^{1}$.

Великий князь направил прошение, зарегистрированное в его канцелярии 20 декабря, исправляющему должность московского обер-полицмейстера полковнику А.А. Власовскому. В ответ начальник полиции 17 января 1896 г. информировал генерал-губернатора, что заявление просительницы о нападении на нее ничем не подтвердилось в ходе проведенного дознания, и добавлял, что Е.М. Вознесенская за последнее время пребывания в Москве «обнаруживала признаки ненормального состояния умственных способностей» ${ }^{2}$.

Спустя полтора года, 25 сентября 1897 г., Е.М. Вознесенская подала новое прошение генерал-губернатору с просьбой о личном приеме. Полковник Д.Ф. Трепов, сменивший к тому времени А.А. Власовского в должности московского обер-полицмейстера, сообщил великому князю в рапорте от 4 ноября того же года, что просительница по указанному ею адресу не проживала, и местонахождение ее неизвестно ${ }^{3}$.

Через некоторое время проводимые розыскные мероприятия привели к успеху. Из канцелярии обер-полицмейстера 20 января 1898 г. в генерал-губернаторскую канцелярию пришло сообщение, где отмечалось, что Е.М. Вознесенская живет по другому адресу, нежели тот, который был указан в ее прошении, средств не имеет и «страдает расстройством умственных способностей в форме нервичного помешательства с бредом преследования». Спустя неделю, 28 января, великий князь, получив эти сведения, предложил обер-полицмейстеру для разрешения ситуации с Е.М. Вознесенской ввиду переполнения московских лечебниц подобными больными обратиться к ее родственникам ${ }^{4}$.

Оказалось, что о судьбе просительницы великий князь Сергей Александрович и его подчиненные беспокоились в гораздо большей степени, нежели ее близкие. Начальник полиции Д.Ф. Трепов в рапорте генерал-губернатору 21 мая 1898 г. сообщал, что обе сестры Е.М. Вознесенской отказались брать заботу о ней, представил их расписки и объяснения, согласно которым одна сестра была вдовой с четырьмя малолетними детьми без достаточных средств, а у другой просто не было средств. В ответ А.Г. Булыгин, московский губернатор, исполнявший в те дни за отсутствием Сергея Александровича обязанности генерал-губернатора, предложил вице-губернатору Л.А. Баратынскому «войти в сношение» с Московской городской управой на предмет помещения Е.М. Вознесенской в психиатрическую лечебницу. Уже 11 июня сам А.Г. Булыгин, вернувшийся к исполнению своих прямых губернаторских обязанностей, сообщал вернувшемуся из поездки великому князю, что городская управа распорядилась о бесплатном помещении просительницы на излечение в Алексеевскую психиатрическую больницу 5 .

Дело Е.М. Вознесенской на этом не кончилось. Уже в следующем, 1899 г., 13 октября и. д. обер-полицмейстера Д.Ф. Трепов рапортовал Сергею Александровичу, что Е.М. Вознесенская вновь появилась в Москве, и от московского городского головы князя В.М. Голицына известно, что она была

1 Центральный государственный архив города Москвы (ЦГА Москвы). ОХД до 1917 г. Ф. 16. Оп. 85. Д. 44. Т. 2. Л. 1-2.

2 Там же. Л. 4-4(об).

3 Там же. Л. 7, 9-9(об).

4 Там же. Л. 10, 11.

5 Там же. Л. 13-16. 
выписана из больницы по прошению сестры, проживавшей во Владимире. Через месяц, 20 ноября, в новом рапорте Д.Ф. Трепов информировал великого князя, что сестра Е.М. Вознесенской ходатайствует об ее освобождении от надзора с разрешением свободного проживания в Москве 1 .

Московский же губернатор А.Г. Булыгин 31 декабря 1899 г. сообщал генерал-губернатору, что Е.М. Вознесенская по-прежнему «страдает хроническим помешательством с бредом преследования» и что «улучшения в ее здоровье не замечалось». В связи с этими обстоятельствами Сергей Александрович 13 января 1900 г. предложил обер-полицмейстеру предупредить сестру Е.М. Вознесенской, что без ее надзора больную, как и прежде, поместят в лечебницу. Через две недели Д.Ф. Трепов уведомил великого князя, что сестре под расписку сообщили условие генерал-губернатора 2 .

По-видимому, сестра действительно взяла на себя заботу о Е.М. Вознесенской, о которой с того времени не было слышно четыре года. Однако 17 февраля 1904 г. из рапорта великому князю от Д.Ф. Трепова, произведенного к тому времени в генерал-майоры и утвержденного в должности обер-полицмейстера, следует, что Е.М. Вознесенская вернулась в Москву. После врачебного освидетельствования она была помещена в Центральный приемный покой для душевнобольных, откуда 15 января 1904 г. была переведена для специального лечения в Преображенскую больницу ${ }^{3}$.

Прошло еще полтора года. За это время великий князь Сергей Александрович покинул должность московского генерал-губернатора, А.Г. Булыгин был назначен министром внутренних дел, а Д.Ф. Трепов - петербургским военным генерал-губернатором. Вскоре великий князь был убит террористом в Московском Кремле. В тревожной обстановке 1905 г., наполненной революционными беспорядками, потомственная почетная гражданка Е.М. Вознесенская вновь напомнила о себе: 19 октября она составила прошение уже новому московскому генерал-губернатору генералу П.П. Дурново с просьбой о личном приеме 4 .

Спустя год, 24 ноября 1906 г., последовало очередное прошение Е.М. Вознесенской к генерал-губернатору (этот пост тогда занимал генерал С.К. Гершельман). Она, как и ранее, пыталась добиться приема, на сей раз обосновывая это тем, что «это дело», т.е. все ее неприятности, создано «возмущением враждебной партии» и что это «закон повелевает дознать» 5 .

Следующее прошение не заставило себя долго ждать: 15 марта 1907 г. Е.М. Вознесенская обратилась к генерал-губернатору, конкретизируя, в чем же заключается дело государственной важности. Она потребовала от С.К. Гершельмана взыскать административным порядком деньги с некоего портного Яшина, который, по словам просительницы, в конце 1904 г. испортил ее вещь. Наконец, через год, 2 апреля 1908 г., Е.М. Вознесенская написала новое прошение по этому же вопросу, которое было решено оставить без последствий 6 .

Материалы дела Е.М. Вознесенской свидетельствуют, что великий князь Сергей Александрович даже в условиях масштабной работы по подготовке коронационных мероприятий в 1896 г. считал необходимым лично разрешать такие проблемы, обстоятельно в них вникая и нацеливаясь на конечный результат. Его преемники на посту московского генерал-губернатора уделили данной ситуации значительно меньшее внимание. Этому может два объясне-

\footnotetext{
1 Там же. Л. 18-18(об), 20.

2 Там же. Л. 22, 24, 25.

3 Там же. Л. 27.

4 Там же. Л. 28.

5 Там же. Л. 30 .

6 Там же. Л. 31-31(об), 34, 36.
} 
ния: либо П.П. Дурново и С.К. Гершельман по-иному расставляли приоритеты в своей деятельности и не стремились особо вникать в подобные ситуации, либо, ознакомившись с отложившимися в деле документами предыдущих лет, не считали целесообразным заниматься данным конкретным случаем.

Исследование выполнено при финансовой поддержке РФФИ в рамках научного проекта № 20-09-41012 Палестина "Дневники великого князя Сергея Александровича, 1895-1897 г2.»

\section{Список литературы}

Боханов А.Н. 1997. Великий князь Сергей Александрович. - Российские консерваторы. М.: Русский мир. С. 323-371.

Великий князь Сергий Александрович на службе Москве и Отечеству: сборник материалов межрегиональной научной конференции. 29-30 мая 2013 г. 2015. М.: Союз Дизайн. 296 с.

Великий князь Сергей Александрович и Великая княгиня Елизавета Федоровна: московский период: избранные статьи (отв. ред. А.В. Громова). XVI-XVIII Елисаветинско-Сергиевские чтения. Москва, 2013-2015 гг. 2017. М.: ЕлисаветинскоСергиевское просветительское общество. 268 с.

Гришин Д.Б. 2006. Трагическая судьба Великого князя. М.: Вече. 304 с.

На службе у России: великий князь Сергей Александрович: материалы научных конференций 2011-2012 гг. Санкт-Петербург - Москва (под ред. И.В. Плотниковой). 2013. М.: Издание Фонда памяти великого кнзя Сергея Александровича. 244 с.

Софьин Д.М. 2021. Великий князь Сергей Александрович: путь русского консерватора. 2-е изд., испр. и доп. М.: Союз Дизайн. 304 с.

SOFJIN Dmitriy Mikhailovich, Cand.Sci. (Hist.), Associate Professor of the Chair of Interdisciplinary Historical Research, Perm State National Research University (15 Bukireva St, Perm, Russia, 614990; sofjindm@yandex.ru) SOFJINA Marina Vladimirovna, Cand.Sci. (Hist.), Associate Professor of the Chair of Documentation and Library Affair and Bibliography, Perm State Institute of Culture (18 Gazety «Zvezda»St, Perm, Russia, 614000; mar-sofina@mail.ru)

\section{THE GOVERNOR-GENERAL IN ACTION: GRAND DUKE SERGEY ALEXANDROVICH AND THE CASE OF ELENA VOZNESENSKAYA}

\footnotetext{
Abstract. In the first months of 1896, preparations were made in Moscow for the coronation celebrations in connection with the wedding of Emperor Nicholas II of Russia to the kingdom. The diary of Grand Duke Sergey Aleksandrovich, the uncle of Emperor Nicholas II, in particular, testifies to the hard work of the Moscow authorities under the leadership of the Grand Duke as the Moscow Governor-General. However, even in such extraordinary conditions, the local authorities of the Moscow governorate under the command of the member of the Russian Imperial House continued to carry out their social function in full, paying attention to the problems of an individual. One of the illustrative examples of such a policy is the case of a Moscow resident, hereditary honorary citizen Elena Voznesenskaya, who suffered from a mental disorder. The case materials show how much attention the authorities paid to such cases, and describe the standard algorithm of their actions for that time, including the role of representatives of state authorities (Governor-General, Chief Police Officer and Governor), their interaction in such situations with local self-government bodies represented by the Moscow City Council.

Keywords: Grand Duke Sergey Aleksandrovich, Russian Imperial House, Moscow governorate, Governor-General, social policy
} 